\title{
Numerical simulation of tsunami generation by cold volcanic mass flows at Augustine Volcano, Alaska
}

\author{
C. F. Waythomas ${ }^{1}$, P. Watts ${ }^{2}$, and J. S. Walder ${ }^{3}$ \\ ${ }^{1}$ U.S. Geological Survey, Alaska Volcano Observatory, Anchorage, AK, USA \\ ${ }^{2}$ Applied Fluids Engineering Inc., Long Beach, CA, USA \\ ${ }^{3}$ U.S. Geological Survey, Cascades Volcano Observatory, Vancouver, WA, USA
}

Received: 18 April 2006 - Revised: 22 June 2006 - Accepted: 22 June 2006 - Published: 26 July 2006

\begin{abstract}
Many of the world's active volcanoes are situated on or near coastlines. During eruptions, diverse geophysical mass flows, including pyroclastic flows, debris avalanches, and lahars, can deliver large volumes of unconsolidated debris to the ocean in a short period of time and thereby generate tsunamis. Deposits of both hot and cold volcanic mass flows produced by eruptions of Aleutian arc volcanoes are exposed at many locations along the coastlines of the Bering Sea, North Pacific Ocean, and Cook Inlet, indicating that the flows entered the sea and in some cases may have initiated tsunamis. We evaluate the process of tsunami generation by cold granular subaerial volcanic mass flows using examples from Augustine Volcano in southern Cook Inlet. Augustine Volcano is the most historically active volcano in the Cook Inlet region, and future eruptions, should they lead to debris-avalanche formation and tsunami generation, could be hazardous to some coastal areas. Geological investigations at Augustine Volcano suggest that as many as 12-14 debris avalanches have reached the sea in the last 2000 years, and a debris avalanche emplaced during an A.D. 1883 eruption may have initiated a tsunami that was observed about $80 \mathrm{~km}$ east of the volcano at the village of English Bay (Nanwalek) on the coast of the southern Kenai Peninsula. Numerical simulation of mass-flow motion, tsunami generation, propagation, and inundation for Augustine Volcano indicate only modest wave generation by volcanic mass flows and localized wave effects. However, for east-directed mass flows entering Cook Inlet, tsunamis are capable of reaching the more populated coastlines of the southwestern Kenai Peninsula, where maximum water amplitudes of several meters are possible.
\end{abstract}

Correspondence to: C. F. Waythomas

(chris@usgs.gov)

\section{Introduction}

Many of the world's active volcanoes are located within a few tens of kilometers of the sea or other large bodies of water. During eruptions, large volumes of volcaniclastic debris may enter nearby water bodies, and under certain conditions, this process may initiate tsunamis (Tinti et al., 1999; Tinti et al., 2003). Worldwide, tsunamis caused by volcanic eruptions are somewhat infrequent (Latter, 1981); however, documented historical cases illustrate that loss of life and property has been significant, sometimes involving thousands of fatalities (Blong, 1984). Thus, it is generally recognized that tsunami generation by volcanic processes is an important and credible hazard.

Volcanic mass flows such as debris avalanches, lahars (volcanic mudflows), and pyroclastic flows and surges commonly develop during moderate to large eruptions (>VEI 2; Newhall and Self, 1982) and they may reach the sea tens of kilometers from their source. Other volcanic processes, such as flank collapse, lateral blast, and pyroclastic fall may introduce material directly into the water which can also trigger tsunamis (Tinti et al., 1999; Ward and Day, 2001; Watts and Waythomas, 2004). In Alaska, many of the volcanoes of the Aleutian volcanic arc (Fig. 1) are partly or entirely surrounded by water, and volcanic mass flows of various types have entered the sea many times in the past 5-10 ka (Waythomas and Watts, 2003). Although only a few historical accounts of water waves generated by subaerial volcanic mass flows and other volcanic processes have been reported in Alaska (Lander, 1996), the combination of an active island arc setting surrounded by deep water suggests that volcanogenic waves may be more significant than presently realized. 

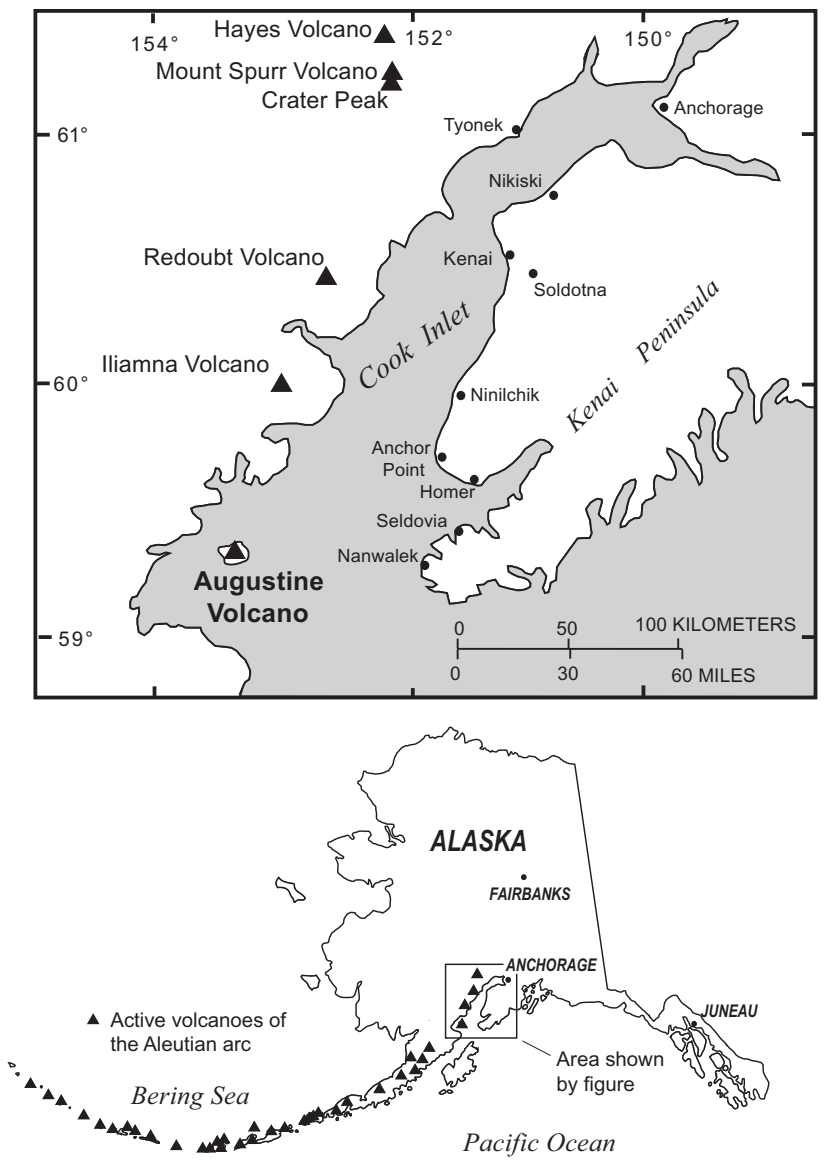

Fig. 1. Location of Augustine Volcano in south-central Alaska and towns and villages along the Cook Inlet coastline. Black triangles locate other volcanoes in the Cook Inlet region.

Here, we focus attention on the process of tsunami generation by volcanic debris avalanches which are gravity driven mass flows of cold, dry, volcaniclastic debris (Ui, 1983; Siebert, 1984). We first define potential tsunami sources by making reference to the morphological characteristics of debris-avalanche deposits on Augustine Volcano, an island volcano in southern Cook Inlet, Alaska (Fig. 1). Then we describe the process of tsunami generation and an analytical procedure for estimating initial tsunami amplitude and wavelength. We chose Augustine Volcano to illustrate our method because the volcano is situated at the entrance to Cook Inlet, a major transportation and economic thoroughfare for Alaska, and is located within a few hundred kilometers of several towns and villages along the coastline (Fig. 1). Augustine is also known to have produced numerous debris avalanches that reached the sea in the past several millennia (Bégét and Kienle, 1992; Waitt et al., 1996). It seems reasonable that some of these debris avalanches may have produced tsunamis (Kienle et al., 1987), although geologic evidence for tsunamis that may have reached the Cook Inlet coastline remains somewhat controversial (Waythomas,
2000). We evaluate conditions required for tsunami generation by debris avalanche, evaluate potential far-field effects, and present a variety of maps depicting the extent of hazard associated with tsunamis reaching coastlines in southern Cook Inlet. The analytical approach we present is flexible and may be easily applied to other volcanoes in the Aleutian arc as well as to other coastal volcanic centers where debris avalanche is a potential tsunami source.

\section{Debris avalanche on Augustine Volcano: potential tsunami source}

Debris-avalanche deposits are ubiquitous in all quadrants on the flanks of Augustine Volcano (Bégét and Kienle, 1992; Waitt et al., 1996). Most of these deposits, which record the collapse of summit lava domes and flows, consist of unsorted mixtures of bouldery rock debris, gravel, sand and silt. Debris-avalanche deposits are exposed in coastal bluffs around Augustine Island and are also inferred in areas just off shore, particularly on the east side of the volcano, where zones of hummocky, irregular bathymetry are present (Fig. 2). Geologic studies of the deposits on Augustine Island have documented at least 12 debris-avalanche deposits, all younger than about 3500 cal yr. B.P. (Bégét and Kienle, 1992; Waitt et al., 1996). These deposits are exposed along the modern shoreline of Augustine Island indicating that they traveled at least as far as the near shore zone around the island.

Augustine Volcano is the most historically active volcano in the Cook Inlet region (Miller et al., 1998) and has had six major eruptions since 1883, including an ongoing eruption that began in December 2005. However, only the 1883 eruption had a large associated debris avalanche, deposits of which are found at Burr Point on the north coast of $\mathrm{Au}-$ gustine Island (Fig. 2). A slightly older eruption at 300$500 \mathrm{cal}$ yr. B.P. also produced a debris avalanche that formed what is now West Island (Fig. 2; Siebert et al., 1995). The young West Island and Burr Point debris-avalanche deposits clearly record large $\left(>0.5 \mathrm{~km}^{3}\right)$ volcanic mass flows that entered the water of southern Cook Inlet under oceanographic conditions essentially the same as today. These flows also are representative of the size and extent of other debrisavalanche deposits on Augustine Volcano (Bégét and Kienle, 1992) and are thus reasonable analogs for future events. A brief description of the Burr Point and West Island debrisavalanche deposits is given next to provide some context for our analysis of tsunami generation by debris avalanche.

\subsection{Burr Point debris-avalanche deposit}

The Burr Point debris-avalanche deposit is located on the north coast of Augustine Island (Fig. 2). Most of the deposit is buried by younger volcaniclastic debris, mainly pyroclastic-flow deposits erupted in 1976, 1986, and 2006. 


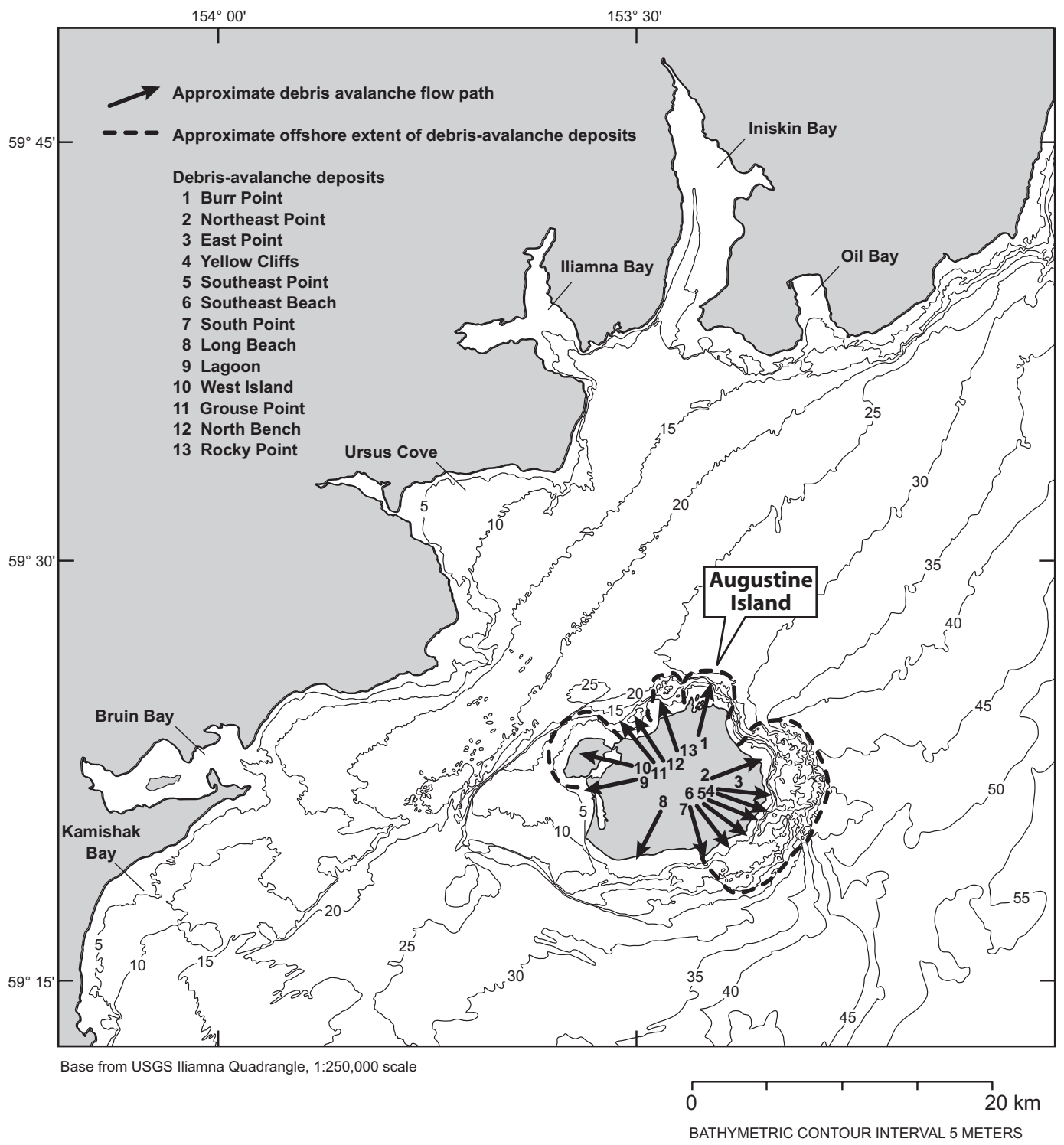

Fig. 2. Bathymetric map of sea floor in the vicinity of Augustine Volcano and location of major bays and coves in the area. Also shown are the approximate flow paths of known debris- avalanche deposits (Waitt et al., 1996) and the approximate offshore extent of hummocky topography interpreted as debris-avalanche deposits.

The distal, seaward part of the deposit has been extensively reworked and modified by tidal erosion (tide range is $6-8 \mathrm{~m}$ ) and storm waves. Some of the unmodified debris avalanche hummocks are overlain by tephra from the A.D. 1912 Katmai eruption and at least one fine tephra of unknown but probable Augustine origin (Waitt et al., 1996). The Burr Point debrisavalanche deposit is thus older than 1912 and is thought to have formed during the 1883 eruption of Augustine Volcano (Siebert et al., 1995; Waitt et al., 1996). According to historical reports, the 1883 eruption occurred when Cook Inlet was at or near low tide (Davidson, 1884). Thus, the Burr Point debris avalanche did not flow directly from Augustine Island into the sea, but crossed a low relief tidal flat several kilometers wide before entering the shallow water of Cook Inlet.

The subaerially exposed portion of the debris-avalanche deposit is about $3.8 \mathrm{~km}$ wide, $2.1 \mathrm{~km}$ long and about $6 \mathrm{~m}$ thick, but individual hummocks and blocks have up to $10 \mathrm{~m}$ of relief. Although the total volume of the debris-avalanche deposit is difficult to determine because some of it is submerged and other parts are covered by younger pyroclastic debris, we estimate that about $8.8 \times 10^{7} \mathrm{~m}^{3}$ of the debris avalanche entered the sea (Table 1). For comparison, the tsunami producing debris avalanches at Unzen and Komagatake volcanoes in Japan had volumes of about $3 \times 10^{8} \mathrm{~m}^{3}$ and the well known debris avalanche at Mt. St. Helens 
Table 1. Geometric properties of debris-avalanche deposits used for tsunami source computations.

\begin{tabular}{lccc}
\hline & Burr Point deposit & West Island deposit & East directed mass flow (hypothetical) \\
\hline Width at shoreline $(\mathrm{m})$ & 5000 & 5000 & 5000 \\
Run out length $(\mathrm{m})$ & 4250 & 3260 & 9330 \\
Average thickness $(\mathrm{m})$ & 6 & 10 & 6 \\
Submerged debris avalanche volume (cubic meters) & $8.8 \times 10^{7}$ & $2.1 \times 10^{8}$ & $8.8 \times 10^{7}$ \\
Orientation of flow path (deg) & 12 & 290 & 90 \\
\hline
\end{tabular}

volcano in the U.S. had a volume of about $2.5 \times 10^{9} \mathrm{~m}^{3}$ (Siebert, 1996).

\subsection{West Island debris-avalanche deposit}

West Island is a prominent debris-avalanche deposit on the northwest side of Augustine Island (Fig. 2) that formed during an eruption 300-500 cal. yr B.P. (Siebert et al., 1995; Waitt et al., 1996). The subaerially exposed portion of the West Island deposit is about $3.2 \mathrm{~km}$ wide, $1.9 \mathrm{~km}$ long and about $6 \mathrm{~m}$ thick. The submarine extent of the deposit is shown on Fig. 2 and the approximate volume of the deposit that entered Cook Inlet is about $2.1 \times 10^{8} \mathrm{~m}^{3}$ (Table 1).

Some areas of West Island have been geomorphically modified by the combined effects of tidal inundation associated with a 6-8 $\mathrm{m}$ tide range, storm surge and possibly erosion by tsunami. Previous studies suggested that the eroded character of West Island is the result of a "great rush of water" across parts of the debris avalanche deposit somehow associated with translation of the debris avalanche into the sea (Waitt et al., 1996).

\section{Debris avalanche motion}

Volcanic debris avalanches are free surface gravity driven flows of dry granular debris, containing particles ranging in size from tens of meters to a few centimeters in diameter. They typically form when a portion of a volcanic edifice becomes unstable and fails, producing a volcanic landslide that transforms to a rapidly moving volcanic rock avalanche. Usually the flows are unconfined and form radially dispersed debris aprons on the lower flanks of their source volcanoes (Siebert, 1984). Some well-known examples include the debris-avalanche deposit at Mt. Shasta (Crandell et al., 1984), and the debris-avalanche deposits at Bandai and Unzen Volcanoes (Siebert et al., 1987). The sedimentological characteristics of debris-avalanche deposits are described in Ui (1983) and Ui et al. (1986). Because we use a volcanic debris avalanche as a tsunami source, it is necessary to describe how the avalanche moves down the flank of the volcano and how we estimate the velocity of the debris avalanche where it strikes the sea.
Precise numerical descriptions of the temporal evolution of gravity driven subaerial mass flows require data and information generally unattainable from study of static mass flow deposits (e.g., Iverson and Denlinger, 2001; Iverson and Vallance, 2001). A simpler but more approximate approach for describing mass flow motion is to use standard equations of motion to evaluate the center of mass translation along the flank of the volcano (Voight and Sousa, 1994; Watts, 1997; Hürlimann et al., 2000; Watts et al., 2003; Watts and Waythomas, 2004). This approach was used by Walder et al. (2003) and Walder et al. (2006) to describe the motion of tsunamigenic subaerial debris flows. Here we implement these ideas into a general model of gravity current center of mass motion that is appropriate for describing the movement of rock avalanches on volcanic slopes.

To develop our model, we consider a gravity driven mass flow moving down a finite, planar slope segment inclined at angle $\theta$ to the horizontal. We discretize the slope into piecewise linear segments where each segment is of constant $\theta$. An equation of motion for instantaneous velocity $u(t)$ along each planar segment has the form:

$\frac{d u}{d t} \approx \frac{B}{A}-\frac{C}{A} u^{2}$

Where the first term on the right hand side of Eq. (1) represents both gravitational acceleration and the effect of bed friction, and the second term on the right hand side of Eq. (1) represents drag by the ambient fluid (air or water). The coefficients $A \equiv\left(\rho_{b}+C_{m} \rho_{o}\right), B \equiv\left(\rho_{b}-\rho_{o}\right) g\left(\sin \theta-C_{n} \cos \theta\right)$, and $C \equiv \rho_{o} C_{d} / 2 L$ are slowly varying functions of time and are discussed more fully in Watts (1997). In these three coefficients, $\rho_{b}$ is the instantaneous bulk density, $\rho_{o}$ is the ambient fluid density, $C_{m}$ is the added mass coefficient, $g$ is gravitational acceleration, $C_{n}$ denotes the instantaneous Coulomb friction coefficient, $C_{d}$ is the total drag coefficient, and $L$ is the instantaneous mass flow length. Plausible bounds for the coefficients are $0.9<C_{m} \leq 1.8,0.05 \leq C_{n} \leq 0.6$, and $0.7 \leq C_{d}<2.1$, depending on the type of failure, slope geometry, materials involved, and type of motion experienced (Watts, 1998; Grilli and Watts, 1999; Watts et al., 2000; Grilli et al., 2002; Enet et al., 2003; Brodsky et al., 2003; Watts and Waythomas, 2004). During subaerial motion, fluid drag 
is negligible and thus $u(t)$ depends primarily on the instantaneous value of the coefficient $B$.

We consider mass flow motion over discrete time steps $\Delta t$, where $\Delta t=t-t_{i}$ the time difference between the beginning and end of the time step, and with the initial condition $u\left(t_{i}\right)=u_{i}$. If $B>0$ (accelerating flow), then the mass flow velocity changes according to

$$
u(t) \cong \sqrt{\frac{B}{C}} \frac{\tanh \left[\sqrt{B C}\left(t-t_{i}\right) / A\right]+u_{i} \sqrt{C / B}}{1+u_{i} \sqrt{C / B} \tanh \left[\sqrt{B C}\left(t-t_{i}\right) / A\right]}
$$

If $B<0$ (decelerating flow) one finds

$$
u(t) \cong \sqrt{\frac{B}{C}} \frac{u_{i} \sqrt{C / B}-\tan \left[\sqrt{B C}\left(t-t_{i}\right) / A\right]}{1+u_{i} \sqrt{C / B} \tan \left[\sqrt{B C}\left(t-t_{i}\right) / A\right]}
$$

Equation (3) improves on the approximate solution for $u(t)$ given by Watts and Waythomas (2004) and is a better solution for mass flow velocity than that obtained from slide block models of mass flow motion (Waythomas, 2000). Finally, if $B=0$, then

$u(t) \cong \frac{u_{i}}{1+u_{i} C\left(t-t_{i}\right) / A}$

Calculation of $u(t)$ typically starts with $u_{i}=0$ at $t_{i}=0$ on a steep slope and is updated by Eqs. (1)-(4) at each time step $\Delta t$ until the mass flow comes to rest. We solve for position $s(t)$ along the incline by integrating the velocity $u(t)$ numerically over time.

We now consider how to scale the deformation of the debris avalanche. If no center of mass motion exists, then no motion occurs and there can be no deformation. Therefore, deformation of the debris avalanche is entirely related to center of mass motion. It is reasonable to use the center of mass motion $s(t)$ as a length scale, rather than the dimensions of the landslide itself (i.e., length, width, thickness). The center of mass motion $s(t)$ drives landslide deformation, and the center of mass motion $s(t)$ in turn depends on the dimensions of the debris avalanche. Watts (1998) used center of mass motion to scale tsunami amplitude, and below we use $s(t)$ to scale deformation of the debris avalanche; this approach is based on the preliminary work of Watts and Grilli (2003).

To account for changes in the shape of the mass flow that occur during transport, some aspects of internal deformation are parameterized in terms of the center of mass motion. These parameters include an acceleration coefficient $k_{a}$, a coefficient accounting for deformation at the snout or nose of the mass flow $k_{n}$, and a length coefficient $k_{l}$. The mass flow center of mass position $s(t)$ can be shifted down slope as internal deformation takes place, amplifying the center of mass acceleration as found by Watts and Grilli (2003). We account for this process approximately by a simple correction applied to the velocity: the value of $(u)$ initially calculated from Eqs. (2), (3), or (4), here denoted as $\tilde{u}$, is adjusted by $u \approx u_{i}+k_{a}\left(\tilde{u}-u_{i}\right)$, where $k_{a} \geq 1$ is a coefficient of order unity that accounts for the amplified center of mass acceleration or deceleration while the mass is shifting. If $k_{a}=1$, then $u=\tilde{u}$; if $k_{a}>1$, then any velocity change in the center of mass is amplified by the deformation of the debris avalanche. If $\left(\tilde{u}-u_{i}\right)>0$, the mass is accelerating, and if $\left(\tilde{u}-u_{i}\right)<0$, the mass is decelerating. Similarly, the nose position $N(t)$ over time can be approximated by adjusting the velocity according to $u \approx u_{i}+k_{n}\left(\tilde{u}-u_{i}\right)$, where $k_{n} \geq 1$ is a coefficient of order unity that accounts for lateral spreading between the center of mass and the nose. This captures the faster motion of the debris avalanche nose relative to the center of mass as shown graphically in Watts and Grilli (2003). The same formula is used because the process of deformation is the same for $k_{a}$ and $k_{n}$. The mass flow length as a function of time $L(t)$ can be approximated by $L(t)=L(0)+k_{l} s(t)$, where $k_{l} \geq 0$ is a coefficient of order unity that relates mass flow length to center of mass displacement. The center of mass motion $s(t)$ was found to be the correct length scale for debris avalanche deformation by Watts and Grilli (2003). Mass flow thickness is estimated from conservation of mass and the three deformation coefficients have values in the range $1 \leq k_{a}<2$, $1 \leq k_{n}<1.4$, and $0 \leq k_{l}<0.8$. These values are based on experimental results (Watts, 1997; Fritz, 2002), numerical analysis (Watts and Grilli, 2003; Locat, et al., 2004), and case studies of mass flow tsunami generation (Greene et al., 2006; Walder et al., 2006).

We use the model described by Eqs. (1)-(4) to evaluate the center of mass motion of volcanic mass flows down the flank of Augustine Volcano to the coastline where they enter the sea. We use the model to solve for mass flow impact velocity $U_{I}$, duration of underwater motion $t_{u}$, and length of underwater run out $r_{u}$, then use these results to construct tsunami sources. We evaluate mass flows analogous to the Burr Point and West Island debris avalanches and a hypothetical debris avalanche on the east flank of Augustine Volcano that has the same submerged volume as inferred for the Burr Point deposit. To do this, we use a submerged volume $V=8.8 \times 10^{7} \mathrm{~m}^{3}$ for a mass flow entering the sea at Burr Point and on the east flank, and $V=2.1 \times 10^{8} \mathrm{~m}^{3}$ for a mass flow entering the sea at West Island. We assume that the volume per unit width is constant, set bulk density $\rho_{b}=1600 \mathrm{~kg} / \mathrm{m}^{3}$, and assume an initial length $L(0)=300 \mathrm{~m}$. We construct piecewise linear transects along the mass flow pathways and use an initial center of mass position at an elevation of 460 $\mathrm{m}$ above sea level, $2-4 \mathrm{~km}$ from the shoreline. We set the center of mass motion coefficients to $C_{m}=1.17, C_{n}=0.25$, and $C_{d}=1.44$, and use mass flow deformation coefficients $k_{a}=1.4, k_{n}=1.16$, and $k_{l}=0.35$ for the results presented here. Although we do not verify this further, the initial tsunami amplitude calculations are not particularly sensitive to expected variations of these six parameters.

In general, the three modeled mass flows have similar durations of motion, fairly well constrained peak velocities, but less well constrained distance of underwater run out (Fig. 3). 


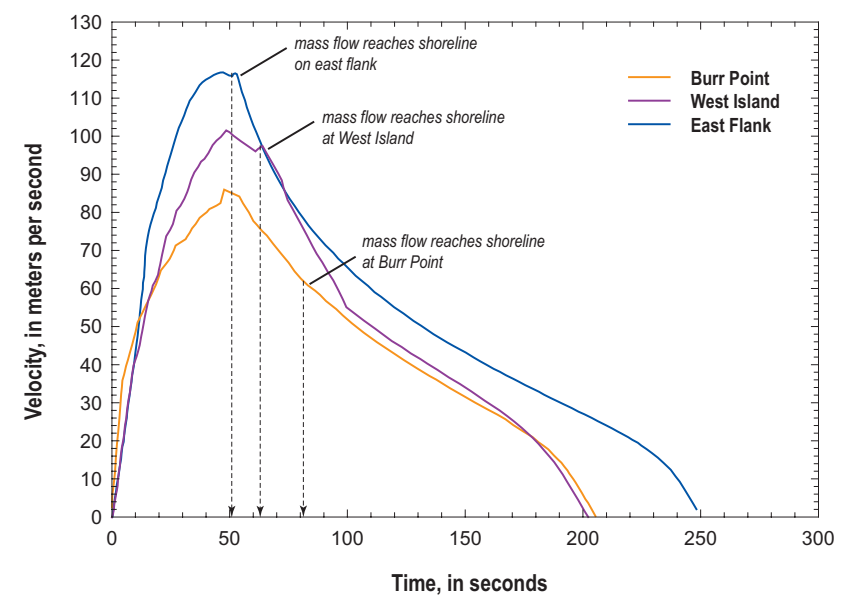

Fig. 3. Center of mass velocity versus time for the three mass flows described in this paper. The velocity at impact with the sea and timing of arrival also shown.

Estimates of run out distance are primarily a function of the initial position of the mass flow center of mass. For all three mass flows, impact with the water occurred 50-100 s after the onset of initial failure. Our calculations yielded typical mass flow impact velocities $U_{I} \cong 60-120 \mathrm{~ms}^{-1}$, duration of underwater motion $t_{u} \cong 125-200 \mathrm{~s}$, and distance of underwater run out $r_{u} \cong 4300-9400 \mathrm{~m}$.

\section{Tsunami generation at Augustine Volcano}

\subsection{Near shore wave behavior}

When a subaerially initiated mass flow strikes the water, the water and the avalanche interact in a coupled manner until the mass flow comes to rest on the sea floor. Recent studies of impact- generated waves have described the region from the shoreline to the area where the mass flow stops on the sea floor as the splash zone (Walder et al., 2003; Walder et al., 2006). The splash zone is an area of complicated wave dynamics and chaotic water behavior (Fritz et al., 2003a; Fritz et al., 2003b; Fritz et al., 2004) and for Augustine Volcano, this zone extends from about 4 to $9 \mathrm{~km}$ beyond the shoreline. Beyond the splash zone is a near-field zone, and this zone is the area of the wave domain where a well defined wave evolves from the splash zone. The far-field zone is the region beyond the near field where steady partitioning of potential and kinetic energy occurs and the leading wave experiences bottom effects, dispersion, and spreading (Mei, 1983). Because it may be necessary to evaluate wave effects at a variety of spatial scales, it is important to recognize that these distinct zones of wave behavior exist and that each zone is characterized by unique wave properties (Walder et al., 2006).

Perhaps the most dramatic aspects of wave generation by subaerial mass flows are within the splash zone where ini-

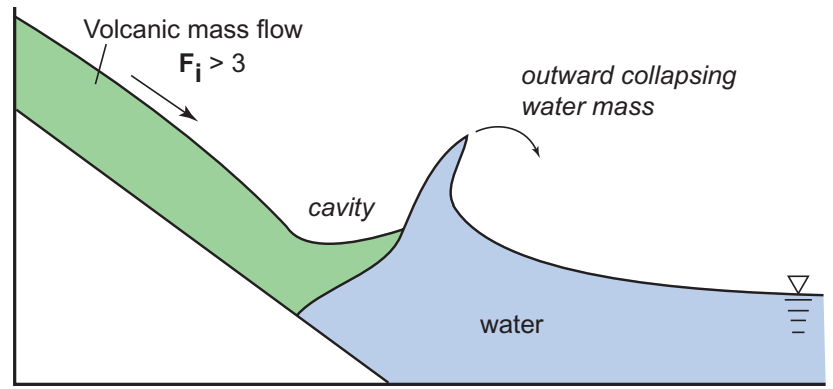

Fig. 4. Schematic representation of an outward collapsing water mass displaced by a mass flow entering the water with an impact Froude number $\left(F_{i}\right)>3.0$. This representation captures the essential features of water behavior in the splash zone.

tial contact with the water body occurs. Wave dynamics in the splash zone are primarily a function of the velocity at first contact with the water (the impact velocity) and mass flow geometry. Wave phenomena in the splash zone are complex and difficult to evaluate quantitatively, especially in nature, where it is typically impractical to obtain data on water behavior. Experimental studies of wave generation by fastmoving granular material have shown that flow separation and cavity development may occur in the splash zone, especially for mass flows with impact Froude numbers $\left(F_{i}\right)>1.6$ (Fritz, 2002; Fritz et al., 2004). $F_{i}$ is defined by the relation:

$F_{i}=\frac{v_{s}}{\sqrt{g h}}$

where $v_{s}$ is the impact speed of the debris avalanche and $h$ is water depth; $F_{i}$ relates the impact speed of the debris avalanche to the propagation speed of the outgoing wave. For typical debris avalanches on Augustine Volcano, we estimate $F_{i}$ to be in the range $3.2<F_{i}<9.6$ for impact speeds of 50 $150 \mathrm{~m} / \mathrm{s}$ and water depth at the point of impact of $20-25 \mathrm{~m}$. Under these conditions, flow separation and cavity development could lead to the formation of an outward collapsing water cavity and a secondary wave train or bore that follows the leading wave (Fig. 4). For water depths typical of the near shore zone surrounding Augustine Island, which are $<25 \mathrm{~m}$, and impact speeds of $50-150 \mathrm{~m} / \mathrm{s}$, values for $F_{i}$ are large suggesting that typical debris avalanches entering the sea at $\mathrm{Au}-$ gustine Volcano may displace water as outward collapsing masses that could evolve or add to a secondary wave train.

\subsection{Initial wave development and the near field zone}

The forgoing discussion provides a contextual framework for wave behavior in the splash zone. We now describe the characteristics of initial tsunami development in the near-field zone. Previous studies have shown that a well defined and coherent wave emerges from the splash zone and the properties of this wave can be used to define the initial tsunami 


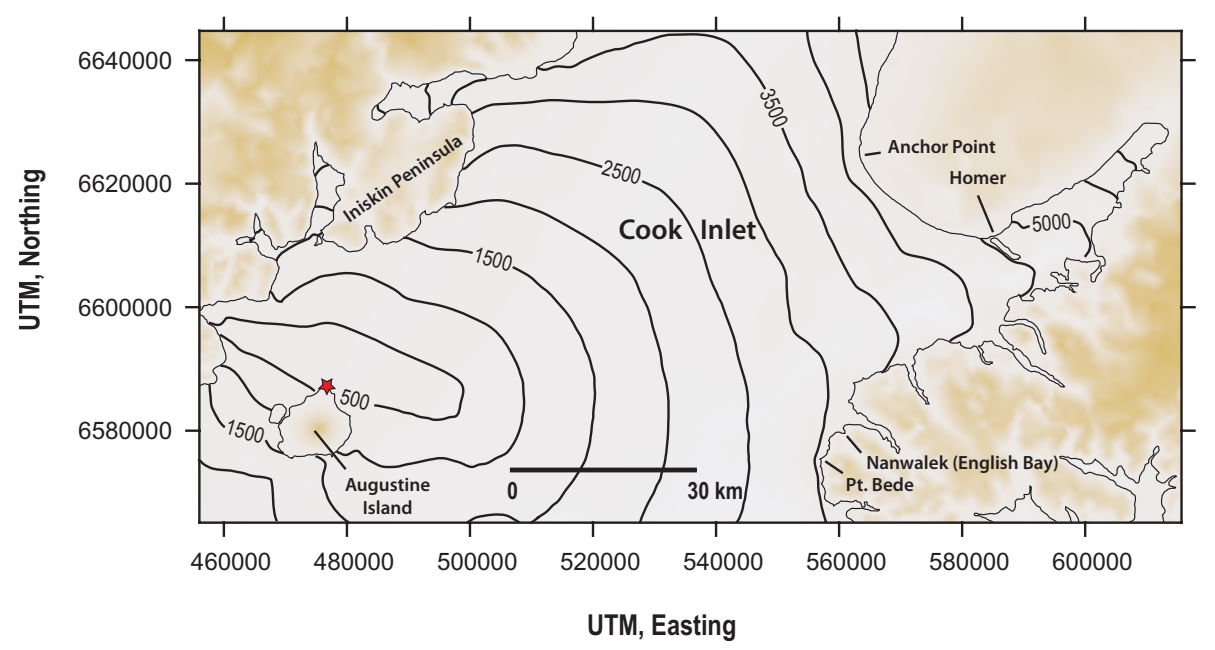

Fig. 5. Map of southern Cook Inlet showing leading wave arrival times (in seconds) for tsunami initiated at Burr Point (location shown by red star). The simulation results indicate that a tsunami with an amplitude of $0.5 \mathrm{~m}$ reaches Homer Spit in about $75 \mathrm{~min}$.

source (Watts et al., 2003; Walder et al. 2003). Wave height $\eta(x)$ in the near field is expressed as

$\eta(x) \approx \eta_{0} \operatorname{sech}^{2}\left(x / \lambda_{0}\right)$

where the origin is arbitrary provided it is set in the near field beyond the splash zone. The initial wave amplitude $\left(\eta_{0}\right)$ and wavelength $\left(\lambda_{0}\right)$ are estimated with the following relations:

$\eta_{0} \approx 1.32 h\left[\frac{t_{s} \sqrt{g h^{3}}}{V_{w}}\right]^{-0.68}$

$\lambda_{0} \approx 0.27 t_{s} \sqrt{g h}$

where $t_{s}$ is the submerged debris avalanche travel time, $g$ is acceleration of gravity, $h$ is water depth, and $V_{w}$ is the submerged debris-avalanche volume per unit width. Equation (7) is valid for $2 \leq t_{s} \sqrt{g h^{3}} / V_{w} \leq 100$. The initial 2$\mathrm{D}$ condition for computational wave propagation simulation is a water wave whose free-surface shape is given by Eqs. (6)-(8). Water velocity beneath the wave is determined from solitary-wave theory (Dean and Dalrymple, 1991; Fritz, 2002).

Using Eqs. (7) and (8) to compute initial tsunami amplitude and wavelength, we find that for waves generated by mass flows similar to the West Island and Burr Point debris avalanches, the maximum wave amplitude is limited by the water depth around Augustine Island within the run out zone of volcanic mass flows which is approximately 20-25 m (Fig. 2). Thus, for reasonable impact speeds of $50-150 \mathrm{~m} / \mathrm{s}, \eta_{0}$ will never be more than about $0.78 \mathrm{~h}$ (Komar, 1998) or about $16-20 \mathrm{~m}$ and $\lambda_{0}$ will be in the range $140 \mathrm{~m}<\lambda_{0}<330 \mathrm{~m}$.

\subsection{Tsunami propagation beyond the near field zone}

To complete our description of the initial wave characteristics, we must account for spreading of the wave front as the initial wave evolves from the near-field zone. Water waves generated by subaerial mass flows tend to be moderately to strongly nonlinear, as indicated by values of the Ursell parameter $\left(\eta_{0} \lambda_{0}^{2} / h^{3}\right)$ commonly in the range 1 to 100 (Watts et al., 2003; Walder et al., 2003). Many shallow-water wave models are not capable of reproducing tsunami inundation for waves of this sort (Watts et al., 2000, 2003) and another approach is to use a wave propagation model based on the Boussinesq approximation which allows the horizontal water velocity to vary with depth. We use the public-domain Boussinesq model FUNWAVE developed by J. T. Kirby and coworkers at the University of Delaware (Wei et al., 1995). FUNWAVE handles frequency dispersion in a manner that correctly simulates deep-water waves, models the fluid mechanics of breaking waves, and simulates inundation. The code properly accounts for wave nonlinearity and handles frequency dispersion in a manner that correctly simulates deep-water waves. The final debris avalanche tsunami source is calculated with a numerical Fortran code called TOPICS (Tsunami Open and Progressive Initial Conditions System; Watts et al., 2000). The tsunami source from TOPICS is used as an "initial" condition for the FUNWAVE calculations. A model called Geowave (Watts et al., 2000, 2003) couples TOPICS and FUNWAVE. Geowave has been applied successfully to a variety of case studies, including pyroclastic flow generated tsunamis (Waythomas and Watts, 2003) and underwater landslide generated tsunamis (Watts et al., 2003; Fryer et al., 2004). Geowave has also been used to evaluate debris flow generated tsunamis in reservoirs (Walder et al., 2006). 


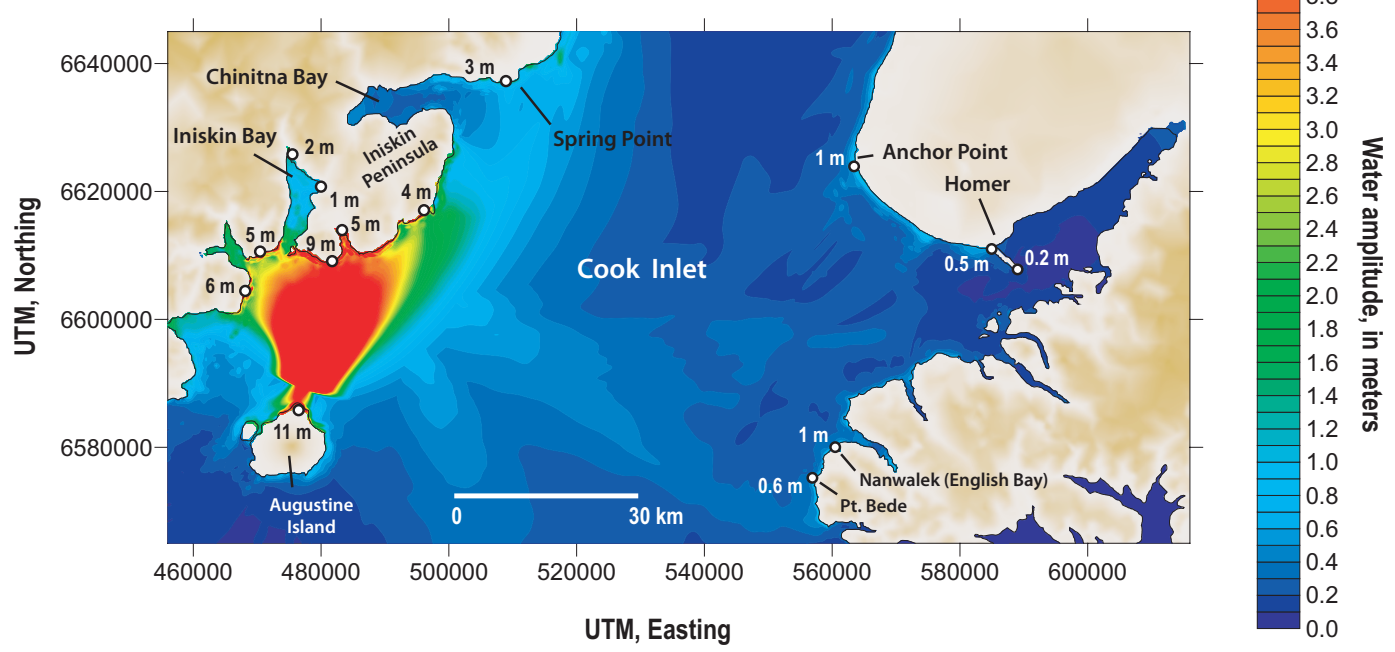

Fig. 6. Map of southern Cook Inlet showing maximum water amplitude for a tsunami initiated by a volcanic mass flow entering the sea at Burr Point. Maximum tsunami amplitude along the southwestern Kenai Peninsula from Pt. Bede north to Anchor point is $\leq 1.0 \mathrm{~m}$. Select local water amplitude maxima also indicated.

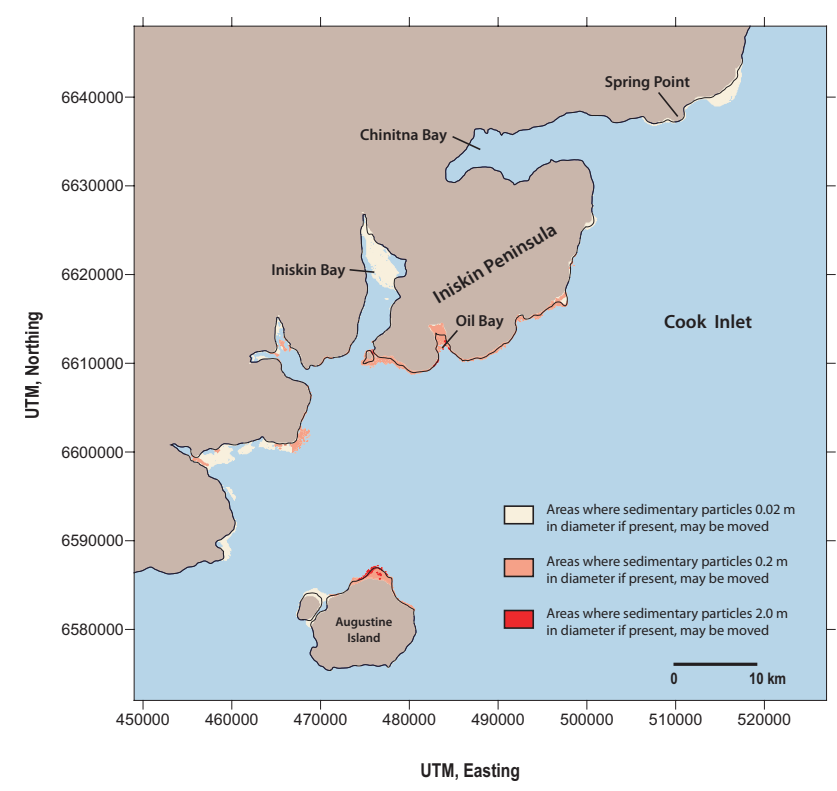

Fig. 7. Map of southwestern Cook Inlet and Augustine Island showing areas where sediment transport by the tsunami initiated by a volcanic mass flow entering the sea at Burr Point could occur.

\section{Results}

The numerical tsunami simulations we present are based on modern day bathymetric sounding data obtained from the National Oceanographic and Atmospheric Administration (NOS Hydrographic Survey Data, Vol. 1, 2, Ver. 4.1). These data were discretized to produce a numerical simu- lation grid with $300 \times 300 \mathrm{~m}$ spacing. We first discuss the results of our numerical simulations of mass flows entering Cook Inlet at Burr Point and West Island and then present results for tsunami generation by a hypothetical mass flow entering the sea on the east side of Augustine Island.

\subsection{Tsunami generation at Burr Point}

Using the physical characteristics of the Burr Point debrisavalanche deposit given in Table 1 and the numerical methods and simulation techniques described above, we describe a debris avalanche that reaches the shoreline with a speed of about $60 \mathrm{~m} / \mathrm{s}$ and travels about $4200 \mathrm{~m}$ beyond the shoreline. We find that a tsunami generated by a debris avalanche entering the sea at Burr Point reaches the coastline of the Iniskin Peninsula due north of Augustine Island in about $25 \mathrm{~min}$, arrives at Nanwalek in about $50 \mathrm{~min}$, and reaches the Homer Spit in about $75 \mathrm{~min}$ (Fig. 5). The maximum water amplitude of the leading wave of the tsunami is shown on Fig. 6 for the coastline north of Augustine Island, and for the coastline of the southwestern Kenai Peninsula. Maximum tsunami amplitudes on parts of the Iniskin Peninsula are up to about $9 \mathrm{~m}$. For areas on the Kenai Peninsula east of Augustine Island, maximum tsunami amplitudes are $<1 \mathrm{~m}$ and at Homer are only about $0.5 \mathrm{~m}$ (Fig. 6). Our simulation results also indicate that at Nanwalek, where a $6-9 \mathrm{~m}$ tsunami was reported during the 1883 eruption of Augustine Volcano (Davidson, 1884), the maximum tsunami amplitude is only $1 \mathrm{~m}$. The discrepancy among the observed and modeled wave heights indicates that either the historical observations are erroneous, as discussed in Waythomas (2000), or the tsunami source parameters we used are incorrect. It is 


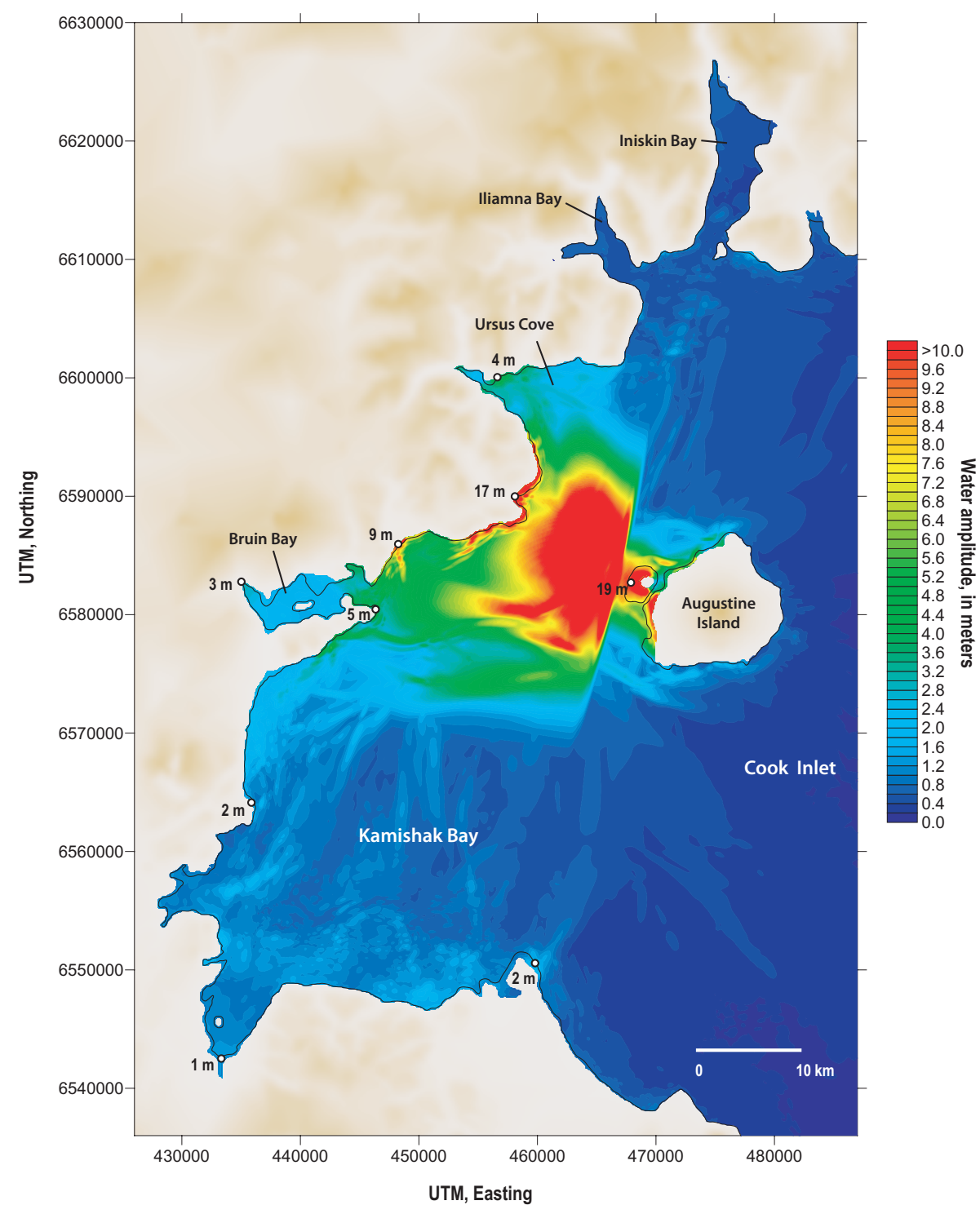

Fig. 8. Map of the Kamishak Bay-Augustine Island area showing maximum water amplitude of tsunami initiated by a volcanic mass flow entering the sea at West Island. Select local water amplitude maxima also indicated.

difficult to justify using a faster moving, larger volume debris avalanche tsunami source because we can not demonstrate that higher impact speeds and larger volume flows are plausible. Also, the shallow water surrounding Augustine Island limits maximum wave amplitude in the near field zone as we have discussed above and if the debris avalanche were emplaced during low tide an even smaller initial wave would have resulted. This leaves open the possibility that the debris avalanche at Burr Point may not have been the source of the 1883 tsunami and some other mechanism, such as a submarine landslide, may have initiated the tsunami observed at Nanwalek.

A derivative application of our simulation results is a sediment transport map showing areas along the coastline where tsunami deposits could form if suitable unconsolidated material is available for transport. Using the numerical methods described in Walder et al. (2006), a map of sediment transport potential was produced (Fig. 7). This map shows that in a few areas along the coast of the Iniskin Peninsula, particles up to $0.2 \mathrm{~m}$ in diameter (cobble and finer size material) if present in the areas indicated could be transported by the tsunami. The utility of this map is that it may be a useful guide to aid in the search for tsunami deposits that could have been formed by the 1883 tsunami.

\subsection{Tsunami generation at West Island}

A debris avalanche entering Cook Inlet at West Island with the physical dimensions and properties given in Table 1 is 


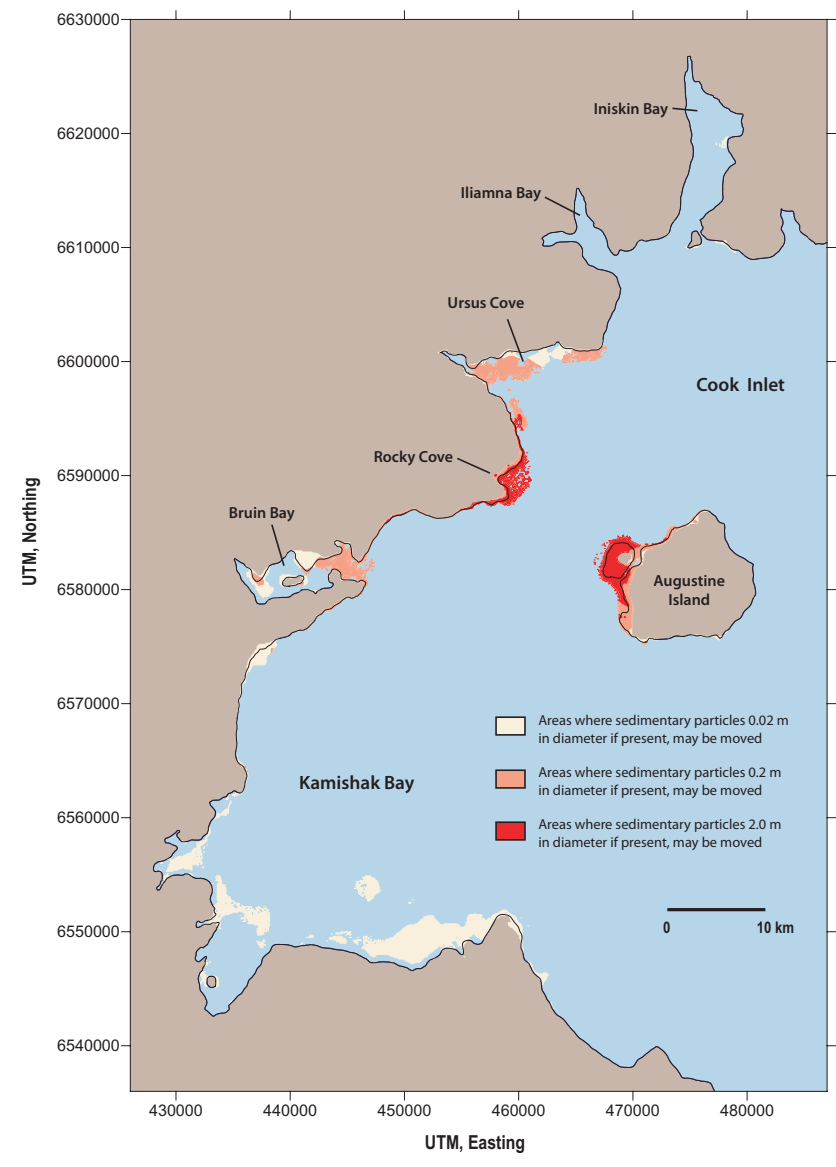

Fig. 9. Map of the Kamishak Bay-Augustine Island area showing areas where sediment transport by the tsunami initiated by a volcanic mass flow entering the sea at West Island could occur.

also capable of producing a tsunami. Our modeling results describe a debris avalanche that reaches the shoreline with a speed of about $97 \mathrm{~m} / \mathrm{s}$ and travels about $6500 \mathrm{~m}$ beyond the shoreline. The tsunami generated by the mass flow travels northwest and is largely confined to the area between Ursus Cove and Kamishak Bay (Fig. 8). The tsunami reaches the northern Kamishak Bay coastline in about 10 min where maximum water amplitudes are 10-17 m (Fig. 8). In Ursus Cove and Bruin Bay, maximum water amplitudes are $3-4 \mathrm{~m}$ (Fig. 8). On Augustine Island itself, the maximum water amplitude from a secondary wave is $19 \mathrm{~m}$ on West Island and up to $10 \mathrm{~m}$ on the west side of the island (Fig. 8). The sediment transport potential of the tsunami is shown on Fig. 9 and indicates that if appropriate sediment is present, areas along Bruin Bay and Ursus Cove could be expected to experience transport of cobble and finer material, whereas clasts up to $2.0 \mathrm{~m}$ in diameter could be transported in the Rocky Cove area (Fig. 9). This suggests that these areas would be good locations to search for tsunami deposits that could be associated with the West Island debris avalanche.
5.3 Tsunami generation by future debris avalanche on east flank

Our final numerical simulation involves a hypothetical debris avalanche entering Cook Inlet from the east flank of $\mathrm{Au}-$ gustine Volcano. We use a physical description of the debris avalanche that is the same as the mass flow entering the sea at Burr Point (Table 1) and find that the flow has an impact velocity of $117 \mathrm{~m} / \mathrm{s}$ and travels about $9400 \mathrm{~m}$ beyond the shoreline before stopping. The resulting tsunami is directed eastnortheast of Augustine Island, reaching the Homer-Anchor Point area in about $1 \mathrm{~h}$ and the Iniskin Peninsula on the west side of Cook Inlet in about 25 min (Fig. 10). Maximum water amplitudes associated with the leading wave of the tsunami are about $5 \mathrm{~m}$ along the coastline in the vicinity of Anchor Point, $3 \mathrm{~m}$ at Nanwalek, and $4 \mathrm{~m}$ at Point Bede (Fig. 11). On the west side of Cook Inlet, the maximum water amplitudes of the tsunami are $2.5 \mathrm{~m}$ at Oil Bay and up to $5 \mathrm{~m}$ along the coast just north of Spring Point (Fig. 11).

Sediment transport potential associated with an east flank tsunami is shown on Fig. 12. There are only a few areas where sediment transport is possible such as at Anchor Point and along the west side of Cook Inlet at the head of Oil Bay and east of Spring Point.

\subsection{Potential hazards}

The numerical modeling scheme used to simulate tsunami generation and propagation also is configured to provide information about some of the potential hazards associated with tsunami waves. Walder et al. (2006) show how the output from the tsunami simulations can be used to develop derivative maps showing the effects of tsunami attack on ships, people, and structures, as well as wave arrival and departure. It is beyond the scope of this paper to describe all of the methods used to make these maps and the reader is referred to Walder et al. (2006) for further details. Below we present a few examples of the types of hazard maps that can be derived from our numerical tsunami simulations. We focus on the possible hazards associated with north and east directed mass flows, because according to our modeling results these have the greatest potential for initiating far field tsunamis.

Figure 13 shows the maximum water velocity, $U_{\max }$, at about one half the water depth for a mass flow initiated tsunami originating at Burr Point (Fig. 13a) and from the east flank of Augustine Volcano (Fig. 13b). These maps provide an example of how the simulation results can be used to evaluate the potential for tsunami waves to displace small boats at anchor. The maximum force required to move an anchor at rest is defined in terms of the "holding power" $\left(F_{h}\right)$ of the anchor (Hunley and Lemley, 1980). Boat anchors may be displaced during a tsunami when the drag force on the anchor line exceeds the holding power of the anchor. The drag 


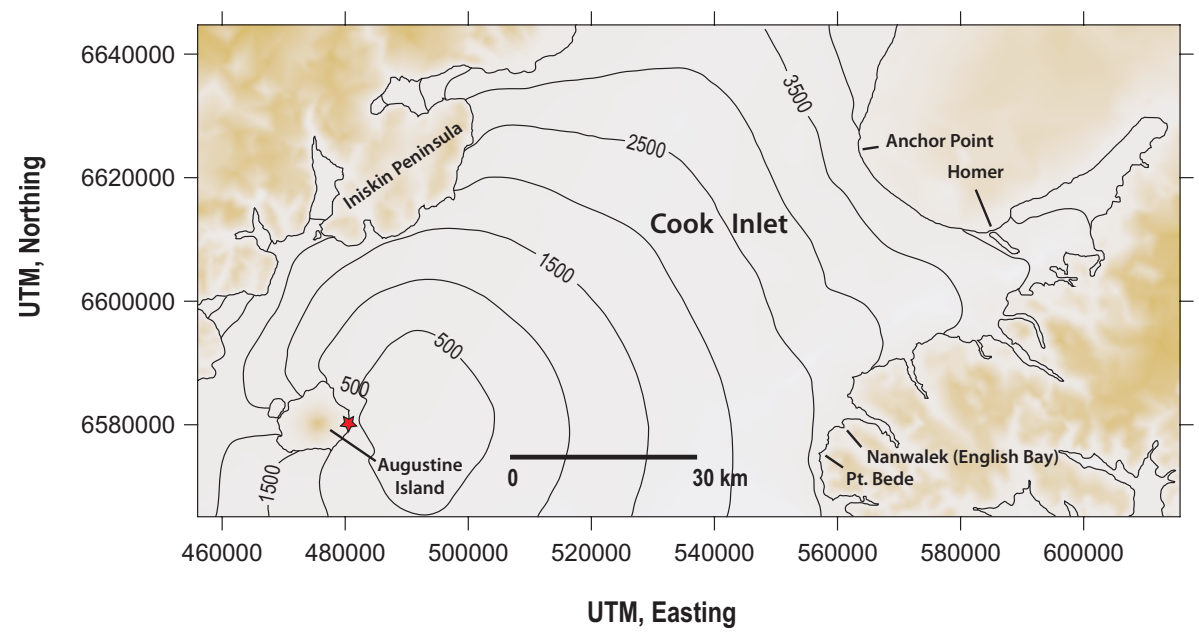

Fig. 10. Map of southern Cook Inlet showing leading wave arrival times (in seconds) for tsunami initiated on the east flank of Augustine Volcano (location shown by red star). The simulation results indicate that a tsunami with an amplitude of $75 \mathrm{~cm}$ reaches Homer Spit in about $65 \mathrm{~min}$.

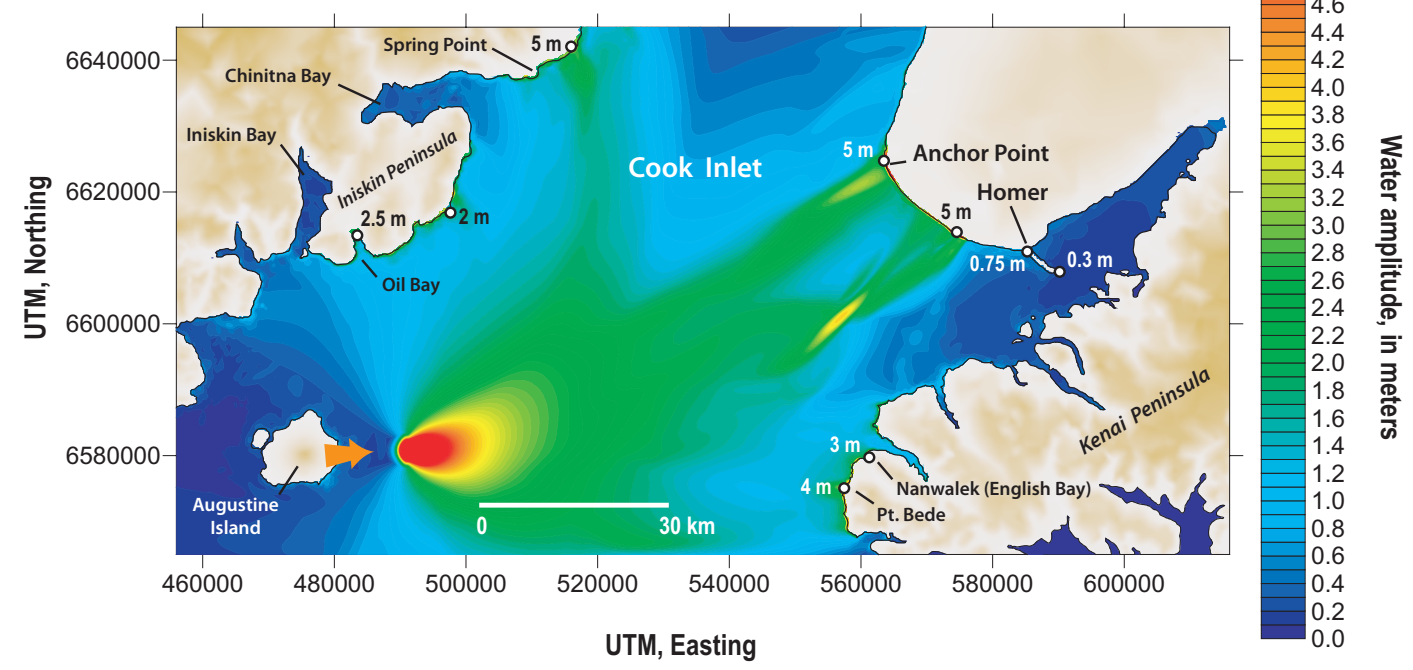

Fig. 11. Map of southwestern Cook Inlet and Augustine Island showing maximum water amplitude of tsunami initiated by a volcanic mass flow entering the sea from the east flank of Augustine Volcano (arrow). Select local water amplitude maxima also indicated.

force $\left(F_{d}\right)$ on the anchor line is given by:

$F_{d} \approx \rho_{w} U_{\max }^{2} h D_{a}$

where $\rho_{w}$ is the density of water, $h$ is water depth, and $D_{a}$ is the diameter of the anchor line. The limiting condition for displacement of the anchor line is

$U_{\max } \approx \sqrt{F_{h} / \rho_{w} h D_{a}}$

The variables $F_{h}$ and $D_{a}$ depend on the type of anchor, substrate conditions, and the size of the boat, and thus, it is not possible to use one value for $U_{\max }$ to evaluate anchor stability during a tsunami. Typical values for small boats are
$F_{h}=300 \mathrm{~kg}$ and $D_{a}=15 \mathrm{~mm}$. Taking $\rho_{w}=1000 \mathrm{~kg} / \mathrm{m}^{3}$ and $h=10 \mathrm{~m}, U_{\max } \approx 1.4 \mathrm{~m} / \mathrm{s}$; if $h=60 \mathrm{~m}, U_{\max } \approx 0.5 \mathrm{~m} / \mathrm{s}$. For the above conditions, small boats anchored in Cook Inlet at water depths in the range of $10-60 \mathrm{~m}$ could be displaced if $U_{\max } \geq 0.5 \mathrm{~m} / \mathrm{s}$. Figure 14 shows areas of the tsunami domain where water velocity $\left(U_{\max }\right)$ is $>0.5 \mathrm{~m} / \mathrm{s},>1.0 \mathrm{~m} / \mathrm{s}$, and $>1.5 \mathrm{~m} / \mathrm{s}$ for a north directed debris avalanche (Fig. 13a) and an east directed debris avalanche (Fig. 13b). These maps indicate where boats at anchor could be displaced and give a sense of the relative risk and areas of safe anchorage.

Although it is unlikely that people would be along the shoreline and caught completely unaware of a tsunami from 


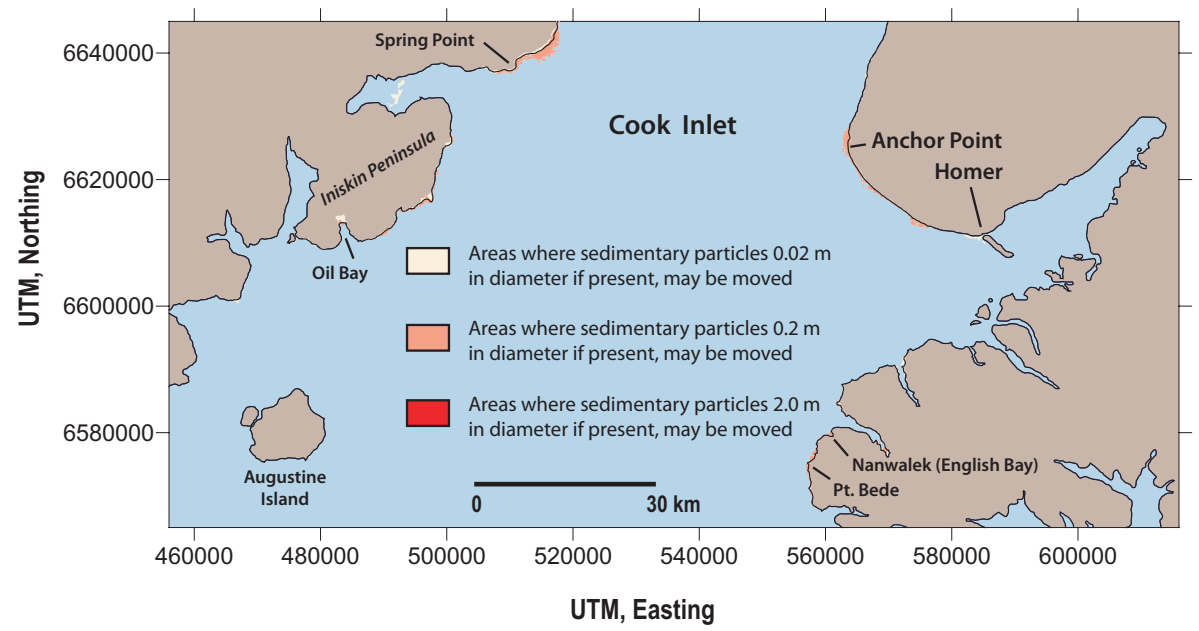

Fig. 12. Map of southwestern Cook Inlet and Augustine Island showing areas where sediment transport by the tsunami initiated by a volcanic mass flow entering the sea on the east flank of Augustine Volcano could occur.

Augustine, the approach of Walder et al. (2006) may be used to illustrate plausible tsunami effects on people. A person will be swept off their feet if the water speed of an incoming tsunami exceeds some critical value $\left(U_{a}\right)$ defined as:

$U_{a} \approx \sqrt{\frac{\mu \mathrm{mg}}{\rho_{w} C_{d} D_{l} D_{a}}}$

where $m$ is the person's mass, $D_{a}$ is distance from the sole of the foot to the ankle, and $D_{l}$ is a typical "diameter" of the leg below the ankle. Equation (11) does not account for the buoyancy effects associated with parts of the body below water. Moreover, for water depth greater than some value $D_{\max }$, which we suggest is about $10 D_{a}$, it is unlikely that an individual could stand upright, even if water velocity is low. Thus, we use the following expression for critical water depth $\left(h_{c}\right)$ :

$h_{c} \approx 10 D_{a}\left(1-\frac{U_{\mathrm{max}}}{U_{\mathrm{ref}}}\right)$

where $U_{\text {ref }}=2.5 \mathrm{~m} / \mathrm{s}$, which is about half of the value of $U_{a}$. We use Equation (12) to define a threshold condition for $h_{c}$ and map out areas where $U_{a}$ and $h_{c}$ are exceeded by the tsunami wave (Fig. 14). This map can be used to indicate potential tsunami hazards to humans along the coastline. The analysis shows that for an east directed wave, hazardous areas along the coastline exist in the vicinity of Homer, Anchor Point, at the head of Kachemak Bay, and at Nanwalek. Various areas along the coastline north of Augustine Island would be hazardous to humans for both east and north directed tsunamis (Fig. 14) although no town or village in this area has a year-round population.

\section{Tsunami hazard relative to storm surge}

To establish a hazard context for tsunamis originating at $\mathrm{Au}$ gustine Island, it is reasonable to compare the results of our numerical simulations, as well as historical reports of waves, to another class of coastal hazard, severe storms and storm surge. Wind-generated storm waves in lower Cook Inlet are a product of the maximum sustained wind, which is defined as the average sustained wind over a period of one minute. The maximum sustained wind has an associated maximum significant wave that is determined from the average height of the highest one third of all waves (Thom, 1973a, b). For lower Cook Inlet, maximum sustained winds of $37 \mathrm{~m} / \mathrm{s}$ (72 knots) have a return period of about 5 years and such winds produce a maximum significant wave of about $12.5 \mathrm{~m}$ (Wise et al., 1977). This is higher than the highest tsunami amplitudes we estimate by numerical simulation, as well as the maximum wave heights reported for the 1883 tsunami. Thus, we reach the perhaps surprising conclusion that wind-generated storm waves are likely to be more severe than tsunamis generated by mass flows from Augustine Volcano. Volcanic unrest at Augustine Volcano may be detected months before an actual eruption (Power, 1988) and the conditions required for flank collapse are unlikely to develop without notice before an event occurs. Thus, in contrast to large wind-driven storm waves, where advance warning may only be a few hours to days, a flank collapse leading to a tsunami could be detected months to weeks in advance of the event. While it is clear that debris avalanche triggered tsunamis at Augustine can form and resulting hazards may be significant, for populated areas along the Kenai Peninsula, it is not likely that these events will be any more severe than large storm waves. 
(a)

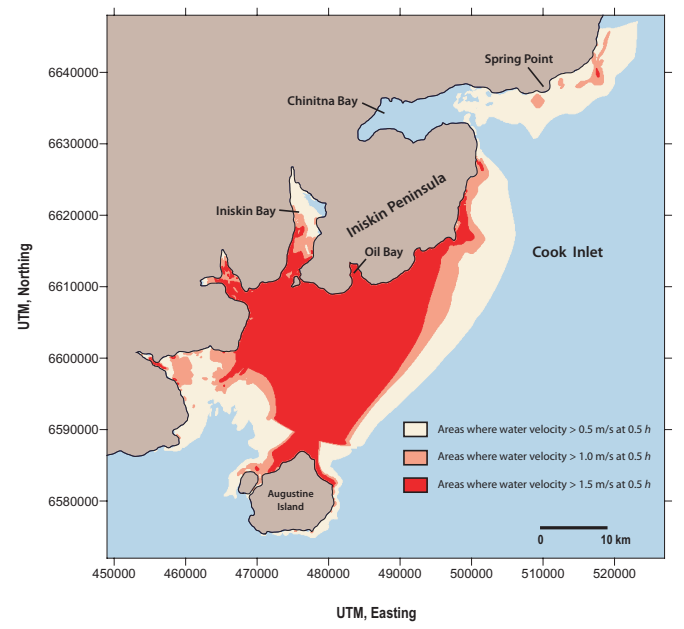

(b)

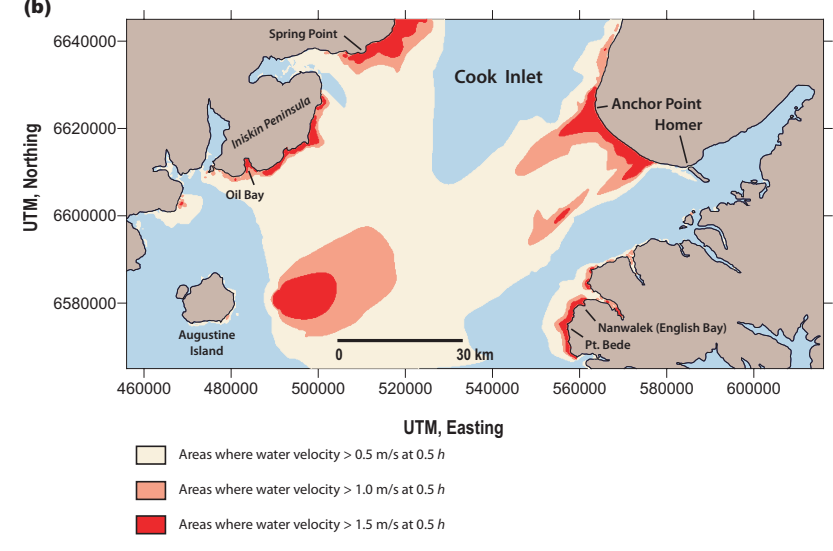

Fig. 13. Portions of the tsunami domain north of Augustine Island where water velocity is greater than $0.5 \mathrm{~m}$ per second, greater than $1.0 \mathrm{~m}$ per second, and greater than $1.5 \mathrm{~m}$ per second during a tsunami initiated by a mass flow entering the sea at (a) Burr Point, and (b) from the east flank of Augustine Volcano. These are areas where small boats at anchor could be displaced by the tsunami.

\section{Discussion and conclusions}

The numerical simulations we present here indicate that cold volcanic mass flows (debris avalanches) originating at Augustine Volcano that enter the sea could trigger tsunamis. Paradoxically, despite the high number of debris avalanches produced at Augustine Volcano during the past several millennia, geologic evidence of tsunami inundation associated with these avalanches is very limited throughout southern Cook Inlet (Waythomas, 2000). The lack of unambiguous geologic evidence for late Holocene tsunami inundation along the coastline of southern Cook Inlet remains enigmatic. Possible explanations include: low tide emplacement of most debris avalanches, inadequate evaluation of proper localities and sites favorable to preservation of tsunami deposits, and lack of suitable source or supply of offshore sediment to produce tsunami deposits. The sediment transport maps we present here could help redirect field studies aimed
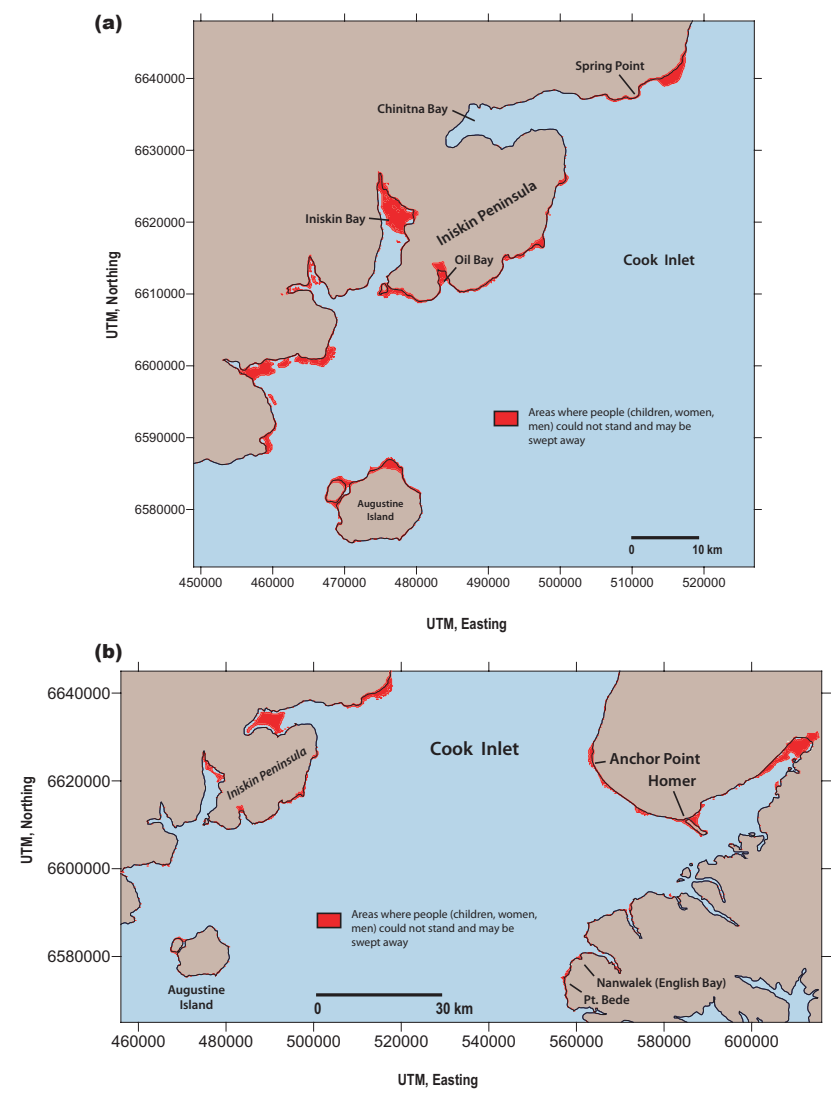

Fig. 14. Areas of the tsunami domain where people could not stand and may be swept away by a tsunami generated by a mass flow entering the sea at (a) Burr Point, and (b) from the east flank of Augustine Volcano.

at finding tsunami deposits. The numerical simulations we performed used a high tide boundary condition, and thus our results provide a "worst-case" scenario for potential tsunami hazards. High tide in southern Cook Inlet occurs twice daily for about four hours each tidal cycle. Our analysis also indicates that east directed debris avalanches similar in size or larger than the 1883 Burr Point debris-avalanche deposit are potentially the most hazardous for areas along the southwestern Kenai Peninsula coastline. Although volcanic mass flows on the east side of Augustine Island have been recognized and mapped (Bégét and Kienle, 1992; Waitt, et al., 1996), and bathymetric information indicates that offshore deposits are present (Fig. 2), these deposits have received far less attention than the Burr Point and West Island deposits and should be a topic of future study. The present summit configuration of Augustine Volcano consists of a nested sequence of lava domes within a small somma-like edifice that is open to the north-northwest. Thus, future eruptions of Augustine Volcano that involve lava dome collapse and debris avalanche formation are likely to be directed to the northnorthwest and not eastward. However, the distribution of known debris-avalanche deposits indicates that all flanks of 
the volcano have been swept by debris avalanches and if conditions at the volcano change rapidly during the course of a future eruption, an east-directed mass flow could occur.

Our simulation results also indicate that mass flow generated tsunamis pose a hazard to people, boats, and structures (should they be erected) along the coastline west and north of Augustine Island from Kamishak Bay north to about Spring Point. Because this segment of the coastline is closest to Augustine Volcano, mass flow initiated tsunamis would affect these areas the most.

Compared to large wind-driven storm waves in southern Cook Inlet with return periods of only a few years, a flank collapse at Augustine Volcano leading to a tsunami is an infrequent event and is not likely to happen without significant precursory activity that would be readily detected. While it is clear that debris avalanche triggered tsunamis at Augustine can form and may pose some significant coastal hazards for areas near Augustine Island. Our analysis indicates that far field wave effects on populated areas along the Kenai Peninsula coastline are unlikely to be any more severe than regularly occurring large storm waves and storm surge.

Acknowledgements. This work was supported by the U.S. Geological Survey Volcano Hazards Program. Mention of product and company names is for identification purposes only and does not constitute endorsement by the U.S. Geological Survey. M. Nathansen, C. A. Neal, T. L. Murray, T. P. Miller, and an anonymous reviewer provided helpful comments on an earlier version of the manuscript.

Edited by: J. Marti

Reviewed by: T. Miller and another referee

\section{References}

Bégét, J. E. and Kienle, J.: Cyclic formation of debris avalanches at Mount St. Augustine Volcano, Nature, 356, 701-704, 1992.

Bégét, J. E. and Kowalik, Z.: Confirmation and calibration of computer modeling of tsunamis produced by Augustine Volcano, Science of Tsunami Hazards, 24, 4, 257-266, 2006.

Blong, R. J.: Volcanic hazards; a sourcebook on the effects of eruptions, Academic Press, Sydney, Australia, 424 p., 1984.

Brodsky, E. E., Gordeev, E., and Kanamori, H.: Landslide basal friction as measured by seismic waves, Geophys. Res. Lett., 30, 24, 2236-2240, 2003.

Crandell, D. R., Miller, C. D., Glicken, H. X., Christiansen, R. L., and Newhall, C. G.: Catastrophic debris avalanche from ancestral Mt. Shasta volcano, California, Geology, 12, 143-146, 1984.

Davidson, G.: Notes on the volcanic eruption of Mount St. Augustine, Alaska, Science, 3, 186-189, 1884.

Dean, R. G. and Dalrymple, R. A.: Water wave mechanics for engineers and scientists. World Scientific, Teaneck, New Jersey, 1991.

Enet, F., Grilli, S. T., and Watts, P.: Laboratory experiments for tsunamis generated by underwater landslides: Comparison with numerical modeling, Proceedings of the 13th Offshore and Polar Engineering Conference, Honolulu, Hawaii, 3, 372-379, 2003.
Fritz, H. M.: Initial phase of landslide generated impulse waves, $\mathrm{PhD}$ Thesis, Swiss Federal Institute of Technology (ETH), Zurich, Switzerland, 2002.

Fritz, H. M., Hager, W. H., and Minor, H.-E.: Landslide generated impulse waves: 1. Instantaneous flow fields, Experiments in Fluids, 35, 505-519, 2003a.

Fritz, H. M., Hager, W. H., and Minor, H.-E.: Landslide generated impulse waves: 2. Hydrodynamic impact craters, Experiments in Fluids, 35, 520-532, 2003b.

Fritz, H. M., Hager, W. H., and Minor, H. E.: Near field characteristics of landslide generated impulse waves, J. Waterway, Port, Coastal, Ocean Eng., 130, 287-302, 2004.

Fryer, G. J., Watts, P., and Pratson, L. F.: Source of the great tsunami of 1 April 1946: A landslide in the upper Aleutian forearc, Mar. Geol., 203, 201-218, 2004.

Greene, H. G., Murai, L. Y., Watts, P., Maher, N. A., Fisher, M. A., Paull, C. E., and Eichhubl, P.: Submarine landslides in the Santa Barbara Channel as potential tsunami sources, Nat. Hazards Earth Syst. Sci., 6, 63-88, 2006, http://www.nat-hazards-earth-syst-sci.net/6/63/2006/.

Grilli, S. T. and Watts, P.: Modeling of waves generated by a moving submerged body: Applications to underwater landslides, Engineering Analysis with Boundary Elements, 238, 645-656, 1999.

Grilli, S. T., Vogelmann, S., and Watts, P.: Development of a 3D numerical wave tank for modeling tsunami generation by underwater landslides, Engineering Analysis with Boundary Elements, 264, 301-313, 2002.

Hunley, W. H. and Lemley, N. W.: Ship maneuvering, navigation, and control, in: Ship Design and Construction, edited by: Taggart, R., Society of Naval Architects and Marine Engineers, New York, 517-532, 1980.

Hürlimann, M., Garcia-Piera, J. O., and Ledesma, A.: Causes and mobility of large volcanic landslides: application to Tenerife, Canary Islands, J. Volcanol. Geotherm. Res., 103, 121-134, 2000.

Iverson, R. M. and Vallance, J. W.: New views of granular mass flows, Geology, 29, 115-118, 2001.

Iverson, R. M. and Denlinger, R. P.: Flow of variably fluidized granular masses across three-dimensional terrain: 1 . Coulomb mixture theory, J. Geophys. Res., 106, 1, 537-552, 2001.

Kienle, J., Kowalik, Z., and Murty, T. S.: Tsunamis generated by eruptions from Mount St. Augustine Volcano, Alaska (USA), Science, 236, 1442-1447, 1987.

Komar, P. D.: Beach processes and sedimentation, Prentice Hall, Upper Saddle River, N.J., 544 p., 1998.

Lander, J. F.: Tsunamis affecting Alaska, 1737-1996, National Geophysical Data Center Geophysical Research Documentation No. 31, U.S. Dept. of Commerce, 195 p., 1996.

Latter, J. H.: Tsunamis of volcanic origin; summary of causes, with particular reference to Krakatoa, 1883, Bulletin Volcanologique, 44, 3, 467-490, 1981.

Locat, J., Lee, H. J., Locat, P., and Imran, J.: Numerical analysis of the mobility of the Palos Verdes debris avalanche, California, and its implication for the generation of tsunamis, Mar. Geol., 203, 3-4, 269-280, 2004.

Mei, C. C.: The applied dynamics of ocean surface waves, World Scientific, Teaneck, N.J., 1983.

Miller, T. P., McGimsey, R. G., Richter, D. H., Riehle, J. R., Nye, C. J., Yount, M. E., and Dumoulin, J. A.: Catalog of the historically active volcanoes of Alaska, U.S. Geological Survey Open-File 
Report OF 98-0582, 104 p., 1998.

Newhall, C. G. and Self, S.: The volcanic explosivity index (VEI): an estimate of explosive magnitude for historical volcanism, J. Geophys. Res., 87(C2), 123-128, 1982.

Power, J.: Seismicity associated with the 1986 eruption of Augustine Volcano, Alaska: University of Alaska Fairbanks, M.S. thesis, 142 p., 1988

Siebert, L.: Large volcanic debris avalanches; characteristics of source areas, deposits, and associated eruptions, J. Volcanol. Geotherm. Res., 22, 3-4, 163-197, 1984.

Siebert, L.: Hazards of large volcanic debris avalanches and associated eruptive phenomena, edited by: Scarpa, R. and Tilling, R. I. Monitoring and mitigation of volcano hazards, Springer, Berlin, 541-572, 1996.

Siebert, L., Glicken, H. X., and Ui, T.: Volcanic hazards from Bezymianny- and Bandai- type eruptions, Bull. Volcanol., 49, 435-459, 1987.

Siebert, L., Bégét, J. E., and Glicken, H. X.: The 1883 and late-prehistoric eruptions of Augustine Volcano, Alaska; models of magmatic processes and volcanic eruptions, J. Volcanol. Geotherm. Res., 66, 1-4, 367-395, 1995.

Thom, H. C.: Distributions of extreme winds over oceans, American Society of Civil Engineers, Waterways, Harbors, and Coastal Engineering Division Journal, 99, 1, 1-17, 1973a.

Thom, H. C.: Extreme wave height distributions over oceans, American Society of Civil Engineers, Waterways, Harbors, and Coastal Engineering Division Journal, 99, 3, 355-374, 1973 b.

Tinti, S., Bortolucci, E., and Armigliato, A.: Numerical simulation of the landslide-induced tsunami of 1988 on Vulcano Island, Italy, Bull. Volcanol., 61, 121-137, 1999.

Tinti, S., Pagnoni, G., Zaniboni, F., and Bortolucci, E.: Tsunami generation in Stromboli island and impact on the south-east Tyrrhenian coasts, Nat. Hazards Earth Syst. Sci., 3, 299-309, 2003,

http://www.nat-hazards-earth-syst-sci.net/3/299/2003/.

Ui, T.: Volcanic dry avalanche deposits - identification and comparison with non volcanic debris stream deposits, J. Volcanol. Geotherm. Res., 18, 135-150, 1983.

Ui, T., Yamamoto, H., and Suzuki-Kamata, K.: Characterization of debris avalanche deposits in Japan, J. Volcanol. Geotherm. Res., 29, 231-243, 1986.

Voight, B. and Sousa, J.: Lessons from Ontake-san: A comparative analysis of debris avalanche dynamics, Eng. Geol., 38, 261-297, 1994.

Walder, J. S., Watts, P., Sorensen, O. E., and Janssen, K.: Water waves generated by subaerial mass flows, J. Geophys. Res., 108, 5, 2236-2255, 2003.
Walder, J. S., Watts, P., and Waythomas, C. F.: Mapping tsunami hazards associated with debris flow into a reservoir, J. Hydraulic Eng., 132, 1, 1-11, 2006.

Waitt, R. B., Bégét, J. E. and Kienle, J.: Provisional geologic map of Augustine Volcano, Alaska, U.S. Geological Survey OpenFile Report OF-96-0516, 1996.

Ward, S. and Day, S.: Cumbre Vieja Volcano - Potential collapse and tsunami at La Palma, Canary Islands, Geophys. Res. Lett., 28, 17, 3397-3400, 2001.

Watts, P.: Water waves generated by underwater landslides, Ph.D. thesis, Div. of Engrg. and Applied Sci., California Institute of Technology, Pasadena, California, 1997.

Watts, P.: Wavemaker curves for tsunamis generated by underwater landslides, Journal Waterway Port Coastal Ocean Engineering, ASCE, 1243, 127-137, 1998.

Watts, P., Imamura, F., and Grilli, S. T.: Comparing model simulations of three benchmark tsunami generation cases, Science of Tsunami Hazards, 182, 107-124, 2000.

Watts, P., Grilli, S. T., Kirby, J. T., Fryer, G. J., and Tappin, D. R.: Landslide tsunami case studies using a Boussinesq model and a fully nonlinear tsunami generation model, Nat. Hazards Earth Syst. Sci., 3, 391-402, 2003, http://www.nat-hazards-earth-syst-sci.net/3/391/2003/.

Watts, P. and Grilli, S. T.: Underwater landslide shape, motion, deformation, and tsunami generation, Proceedings of the Thirteenth International Offshore and Polar Engineering Conference, Honolulu, HI, 364-371, 2003.

Watts, P. and Waythomas, C. F.: Theoretical analysis of tsunami generation by pyroclastic flows, J. Geoph. Res., 108, 12, 25632584, 2004.

Waythomas, C. F: Reevaluation of tsunami formation by debris avalanche at Augustine Volcano, Alaska, Pure Appl. Geophys., 157, 6-8, 1145-1188, 2000.

Waythomas, C. F. and Watts, P.: Numerical simulation of tsunami generation by pryoclastic flow at Aniakchak Volcano, Alaska, Geophys. Res. Lett., 3014, 1751-1755, 2003.

Wei, G., Kirby, J. T., Grilli, S. T., and Subramanya, R.: A fully nonlinear Boussinesq model for free surface waves, Part 1: Highly nonlinear unsteady waves, J. Fluid Mech., 294, 71-92, 1995.

Wise, J. L., Searby, H. W., Brower, W. A., Diaz, H. F., and Prechtel, A. S.: Climatic atlas of the outer Continental Shelf waters and coastal regions of Alaska, Vol. 1, Gulf of Alaska, U.S. Dept. of Commerce, NOAA, Alaska Outer Continental Shelf Environmental Assessment Program Final Report, 339 p., 1977. 